\title{
MERGERS AND PREVENTIVE ANTITRUST POLICY
}

\section{George J. Stigler $\dagger$}

A distinction may be drawn between two kinds of antitrust law, the preventive and the corrective. The preventive seeks to outlaw those forms of behavior which, if pursued far enough, reduce or eliminate competition. The corrective seeks to eliminate monopolistic power already in existence, or at least to curb certain exercises of this power. Undoubtedly, there are policies that fall on the borderline between these categories, but in general, the distinction can be made with tolerable certainty.

Almost all of the American antitrust law is corrective. This need not be argued for the Sherman Act, and I think that it is almost as true of the Clayton Act. The latter's prohibitions upon price discrimination and tying-clauses apparently were adopted in part to prevent the appearance or spread of monopoly, but it is evident that both types of policies can arise only when monopoly power is already possessed. No competitive seller will continually accept a lower price from some buyers than he can get by diverting his goods to other buyers; ${ }^{\mathbf{1}}$ and no buyer with adequate alternative supply sources will accept the limitations imposed by tie-in sales or total requirements contracts without an offsetting reduction in price. Section 7 of the Clayton Act, ${ }^{2}$ the antimerger section, is the only important instance of preventive antitrust legislation. $^{3}$ I shall discuss this section after briefly discussing the general problem of preventive antitrust policy.

$\dagger$ Professor of Economics, Columbia University. Member, Attorney General's National Committee To Study the Antitrust Laws. B.B.A., 1931, University of Washington; M.B.A., 1932, Northwestern University; Ph.D., 1938, University of Chicago.

1. The widespread opposition to this view even among disinterested students has impressed itself upon me in the course of the deliberations of the Attorney General's National Committee To Study the Antitrust Laws. A good deal of the opposition is due to the fact that non-economists look only at the nominal price, whereas the economist uses "price" to denote all the conditions of sale, including, e.g., the credit rating of the buyer. Part of the opposition arises also from the perennial, and at times perhaps deliberate, confusion between sporadic and systematic price discrimination. The Report of the Atrorney General's Natronal Conmittee To STUDY THE ANTITRUST LAwS (1955) (hereinafter cited as REPORT) is not free from this latter confusion. See REPORT at $218,336$.

2. 38 STAT. 731 (1914), as amended, 15 U.S.C. \$ 18 (1952).

3. Perhaps the FTC's mandate to eliminate unfair methods of competition works in the same direction; but unfair methods of competition are probably at least as pervasive among small businesses as large, and the common types of FTC cases have only modest relevance to monopoly. 


\section{Preventive An'titrust Policy in General}

In the nature of things, a preventive antitrust policy cannot be wide-flung. An antitrust policy is employed by a society which wishes to use the competitive market, rather than powerful private or public bodies, to regulate most economic activity. Many business activities could lead to monopoly. Some, like innovation, are generally applauded; some, like advertising, have more equivocal reputations; and some, like moving to low wage sections, are all too widely deplored. If a society were to intervene in every activity which might possibly lead to a reduction of competition, regulation would be ubiquitous and the whole purpose of a public policy of competition would be frustrated.

The policy of competition rests upon the assumption that economic forces will go far toward preserving a competitive economy, so that only a moderate amount of preventive (and corrective) antitrust action is necessary to achieve a tolerably satisfactory level of competition. This assumption is today almost an American monopoly; most Europeans believe that competition is self-destructive, and their confidence in this belief has not been diminished by the enormous efforts they expend in suppressing competition. But I accept the assumption as a fundamental empirical truth; the history of the American economy in the twentieth century testifies that a modest program of combatting monopoly is enough to prevent any considerable decline in competition.

A preventive antitrust policy, therefore, should be directed at activities which on their face have a general and important tendency to reduce competition, and only at such activities. Mergers of business rivals are unique in the degree to which they meet this requirement. By definition, they involve at least a temporary reduction in the number of independent enterprises in the industry. This is, indeed, their chief purpose; historically the other purposes of mergers (of large firms) have been incidental and unimportant. ${ }^{4}$ The control of mergers since 1890 would have given us an industrial structure substantially less concentrated than that we now possess.

The only other type of business activity that seems to invite preventive antitrust policy is the cooperation of firms within an industry -which is economically only an incomplete form of merger. But here, in contrast with mergers, the difficulty is that there are many justifiable as well as many unjustifiable forms of cooperation. When an industry seeks to standardize its products or engages in joint re-

4. In recent times, the avoidance of taxes has become a significant force in bringing about mergers. See BUTTERs, LINTNER \& CARY, EFFECTS of TAXATION: CoRPORATE MERGERS (1951). Taxes, while often an inducement to sell a flourishing enterprise, are not the reason why the sale is made to a business rival. 
search or defends itself against attacks by other industries (e.g., margarine $\mathrm{v}$. butter), no antitrust questions need be raised. In fact, such cooperation is almost identical from an economic viewpoint with purchase of the activity from an outsider : the industry may collect its own market information, or it may buy the information from a McGrawHill publication. There appears to be no feasible distinction, from the standpoint of preventive antitrust policy, between forms of cooperation which may reduce competition if pursued far enough, and those which will leave competition unimpaired. ${ }^{5}$ The Attorney General's Committee is probably right in believing that each class, although not each instance, of trade association activities should be judged separately. ${ }^{6}$

In addition to these general types of preventive antitrust policy, there are many ad hoc policies, most of which stem from the economic activities of government. Thus the government plant disposal programs, the licensing of sequestered foreign patents, armed forces procurement policy and sundry other government policies have paid some attention to the preservation of competition. Very possibly the list of such policies should be lengthened; for example, the vast research expenditures of the Federal Government now go chiefly to large business enterprises which are allowed to own the patents resulting from the government-financed research, and it is not obvious that this scheme pays adequate attention to competition and other social goals. But these ad hoc policies raise fewer questions of principle than of fact, and we shall not examine them here.

\section{MERGERS}

The amended section 7 of the Clayton Act is an untested part of the antitrust laws, and thus poses an especially troublesome problem to the antitrust agencies. They naturally fear to spell out in a concrete and meaningful fashion the specific criteria of mergers which reduce competition to an illegal extent. Lacking extensive experience in enforcement; they could easily devise criteria which have large and embarrassing loopholes, or alternatively, the criteria might prove obstructive of innocent and even desirable mergers. Considerations such as these presumably explain, and possibly even justify in part, the evasive action taken by the enforcement agencies when asked for criteria.

But such considerations do not dictate an equal measure of evasiveness by the Attorney General's Committee which, after all, was not burdened with judicial authority or administrative powers. Yet the

5. Of course, one can distinguish certain forms of cooperation which immediately reduce competition, but their control is part of corrective antitrust policy.

6. REPORT at 19-24. 
Report lists several pages of "factors" which should be taken into account in judging the legality of a merger; the following is a distressingly representative sample of this listing:

"(a) What companies buy or sell in the market, how many, and what are the significant differences among them: (i) large, medium, and small (market shares, or rank of large companies, etc.) ; (ii) degrees of vertical integration; (iii) uses of the product; and (iv) the significance of the product under study in the output or in the purchases of different companies." 7

Ignoring the naked ambiguity of some phrases such as (iii), it will be observed that nothing is said of how these factors work. For example, there is no hint as to whether the presence of large buyers or the existence of vertical integration serves to make an otherwise debatable merger more or less objectionable.

It is one thing to recognize that there will necessarily be some difficult and puzzling borderline cases in the enforcement of the new section 7; it is another and very different thing to assume that one must approach the interpretation and enforcement of the section in a purely ad hoc manner. We should not entrust the administration of general statutes to enforcement agencies with the lonesome admonition that they should act in the public interest. I propose to discuss some possible criteria and problems in the enforcement of the anti-merger section.

\section{Horizontal Mergers}

Much discussion of section 7 implicitly seems to assume that its chief applicability will be to the firm that engages in a succession of mergers, each raising its share of the industry's output by a fairly small percentage. The question of the effect of any one merger on competition then becomes: which straw breaks a camel's back? This is a real problem, ${ }^{8}$ but surely its importance is much exaggerated. Often a single merger will substantially reduce competition: some camels try to haul pianos.

The elimination of mergers which certainly or almost certainly reduce competition by a very substantial amount may, in fact, prove to be the chief contribution of the new section 7. Many of these mergers would be within the reach of the Sherman Act, it is true, but the less exacting standards of the Clayton Act will greatly simplify the task of prohibiting such mergers. Moreover the amended section 7 will serve

7. Id. at 126.

8. See pp. 180-83 infra. 
as a prod to the Department of Justice, which has almost completely ignored the task of enforcing the Sherman Act prohibitions of unconsummated attempts to monopolize. ${ }^{9}$

The most difficult task in devising criteria of the applicability of section 7, however, arises for the mergers which are not sufficiently large relative to their industries as to become probable or palpable Sherman Act cases. Here one can proceed along two very different, but not inconsistent, lines.

The first line employs a legal criterion. If, in the industry, there have been significant instances of conspiracy or attempted conspiracy in restraint of trade, then any merger of two or more firms of substantial size should be forbidden. A conspiracy to restrain trade is easier to form, and more effective in its operation, if the firms in an industry are fewer and the leading firms are larger. A past record of conspiracy shows that the number is already too small, or the relative size of some firms is already too great, to allow a further weakening of the forces of competition.

This criterion of monopolistic history is very powerful; it dictates, for example, that there should be no mergers by the larger companies in steel and cement which have records of conspiracy through basing point price systems. It dictates that there should be no mergers in industries characterized by frequent antitrust violations, such as various kinds of electric lamps and lights, movie exhibition and abrasives. Only if the attempts at conspiracy were absurd and unrealistic gestures, condemned in advance by market realities, could one dismiss this sort of proof of present or incipient overconcentration within an industry.

The second line of analysis is more directly economic. The basic test of an undesirable merger is that, if the merging firm continues this type of merger activity, competition will be appreciably reduced. It requires only a moment's thought to reveal that this basic test is not easily translated into objective and manageable criteria. Even a low rate of merger, if continued long enough, may lead to high concentration and reduce competition substantially. If the merging firm begins to raise prices, often other firms will be attracted to the industry, so should one not also predict the rate of entry of new firms? Aside from questions of fact about the history of mergers and entry of firms-which can be troublesome enough, of course-we must make decisions as to (i) what a critical level of concentration may be; (ii) the time horizon we employ; and (iii) what may be the costs of excessive zeal in combatting mergers. 
The level of concentration which seriously threatens competition still eludes precise determination by the economist. We all recognize that in a properly defined industry, if the largest firm has less than ten per cent of the output, competition will be effective-in the absence of collusion which itself generally will be less probable and effective when concentration is low. And when one firm has forty or fifty per cent or more, or two to five firms have seventy-five per cent or more of the industry's output, competition will seldom plague the industry. Between such widely separated limits, the level of concentration which poses a serious threat to competition will vary with the ease with which new firms can enter the industry, the rate of growth of the industry, the closeness of substitute products made by other industries and their competitive organization and other factors.

To this area of uncertainty, one must add that of the time period over which we should extrapolate the recent trends of concentration. If we use a very long period, almost all mergers are suspect; if we use a very short period, we are simply discussing a single merger and thus ignoring the possibility that the reduction of competition may be a process as well as an event. But this is really a minor problem, I conjecture. Firms which are seeking a commanding position in their industry move swiftly as a rule, and a very few years-say five-should usually be sufficient to reveal their plans.

We cannot prohibit all classes of mergers which might conceivably reduce competition without interfering with legitimate and desirable mergers which have no adverse effect, or only a negligible effect, upon competition. Moreover, it is necessary to recognize the possibility that some mergers which raise concentration or reduce an already small number of firms may increase competition. This situation may arise when the small firms in an industry are relatively inefficient and cannot survive as independent enterprises; if they can survive by merging, the number of effective competitors in the industry is increased. ${ }^{10}$ The recent mergers of the small firms in the automobile industry were presumably tacitly approved by the antitrust agencies on this line of thinking, and conceivably properly so.

Those mergers which increase both concentration and competition are most uncommon, however. In industries where one must produce

10. The Report mentions two other types of mergers which may serve desirable ends. First, ". . . mergers may ease from the market companies which have failed in the competitive struggle and thus prevent potential bankruptcies." REPORT at 124. It is not explained why the acquiring firm should pay more than a bankruptcy price, unless it is also acquiring some market control. Second, ". - [mergers] may spur operating economies by spreading overhead costs. ..." Id. at 125 . This is simply inaccurate arithmetic; the merged firm has the sum of the overhead costs of the constituent firms and presumably no greater output. In any case, spreading-or piling up-overhead costs is no spur-or bridle-to operating economies. 
a fifth or more of the nation's output in order to achieve an efficient or profitable productive technique, competition will be weak whether one does or does not allow mergers. If the economies of scale are not substantial, the proper social policy would be to dissolve the giant firms rather than to allow mergers of the small; if the economies of scale are substantial, then competition cannot be used to regulate the industry.

Proposals for the enforcement of the anti-merger statute should also take into account the practical limitations on the investigations that the enforcement agencies can make. It would be absurd to expect a thorough investigation of each of the hundreds or thousands of mergers of interstate commerce dimensions that occur each year. One must eliminate the vast majority of mergers from review, but the elimination should be made on the basis of presumptive legality and economic unimportance, and not-presumably, as at present-on the basis of the caprice of notoriety.

I should think that the foregoing considerations are best met by a set of rules such as these:

1. There should be a presumption that every firm with less than five to ten per cent of an industry's output (after merger) may engage in the merger. Within this range, the percentage should be lower, the larger the industry.

2. Every merger by a firm which possesses one-fifth or more of an industry's output after the merger shall be presumed to violate the statute. ${ }^{11}$

3. In the situations that lie between these limits, the merger should be investigated by the enforcement agencies if the aggregate annual sales of the merging firms will exceed some absolute level-say five million dollars-after merger. ${ }^{12}$ Its legality should be judged along the lines discussed above.

A set of rules such as these would serve the double purpose of giving the business community some advance knowledge of public policy toward most mergers, and of achieving the important goals of the legislation.

11. It is interesting to notice that in the recent complaint against Schenley Industries, Inc., for acquiring control of Park \& Tilford, the merged firm is near this borderline of one-fifth. The merged firm would have $20.5 \%$ of productive capacity, $26 \%$ of production, $17 \%$ of bottled whisky, $19 \%$ of storage capacity, $22 \%$ of inventories and $19 \%$ of dollar volume of sales, according to the complaint. United States v. Schenley Industries, Inc., Civil No. 1686, D. Del., Feb. 14, 1955.

12. Such a cut-off point has economic as well as administrative justification. A monopolist of small absolute size will normally be encroached upon by new rivals much sooner than a monopolist of large absolute size. See my introduction to Business Concentration and Price Poltcy (1955). 


\section{Vertical Integration}

The foregoing discussion pertains only to horizontal mergers, i.e., mergers of firms within the same industrial category. Both the Report and the literature of antitrust have devoted considerable attention to two other categories of mergers: the vertical integration of enterprises, and the conglomerate firm.

It is not obvious that the vertical merger has any direct antitrust relevance. Suppose that there are one hundred firms (of reasonably similar sizes) in each of the consecutive processes of spinning, weaving and dyeing a particular textile. Each process will be competitively organized. . Suppose that there is universal vertical integration, so that instead of 300 firms, one hundred in each process, we now have one hundred firms, each operating in all three stages. Why should not all the processes still be competitive?-we have just finished saying that one hundred firms in any industry are sufficient for competition. Except in empirically unimportant cases, there is no reason to expect that vertical integration has any monopolistic implications so long as every stage of production is competitive. ${ }^{13}$

Of course vertical integration loses its innocence if there is an appreciable degree of market control at even one stage of the production process. It becomes a possible weapon for the exclusion of new rivals by increasing the capital requirements for entry into the combined integrated production processes, or it becomes a possible vehicle of price discrimination. ${ }^{14}$ In these cases new vertical mergers are not desirable, and one should supplement our rules with an additional one:

4. Where a firm has a fifth or more of an industry's output, its acquisition of more than five to ten per cent of the output capacity of industries to which it sells or from which it buys in appreciable quantities shall be presumed to violate the statute.

This rule is simply an adaptation of rules 1 and 2 .

\section{Conglomerate Mergers}

Conglomerate mergers owe much of their current interest, and perhaps their intellectual parentage, to Corwin Edwards, who has portrayed them as a menacing but elusive form of organization. ${ }^{15}$ The

13. The one probable effect upon competition is indirect. It may be true of certain industries that the firms most likely to enter them are firms which sell to or buy from them. Then vertical integration would reduce the number of potential entrants, and in borderline cases (hence the empirical unimportance of the exceptions) decrease somewhat the competition within a given stage of production.

14. See Stigler, The Division of Labor Is Limited by the Extent of the Market, 59 J. Por. Econ. 190-91 (1951).

15. See Edwards, Conglomerate Bigness as a Source of Power, in Busrness Concentration and Price Policy (1955). 
essence of this type of firm, as I understand it, is that although the firm need not have an appreciable degree of market control in any one market, yet because of the many markets in which it operates and the large resources it possesses, a power is acquired to sell and buy at preferential terms. I must confess that the exact mechanics by which the total power possessed by the firm gets to be larger than the sum of the parts (in individual markets) escape me, and I am not sure that there are any companies that meet the specifications of the conglomerate firm. There is a certain resemblance between Edwards' concept and the structure of, e.g., duPont, but duPont has monopoly power in many markets, and therefore one does not have to resort to conglomerateness to explain its power and prosperity.

If there are conglomerate firms, I suspect that their chief sins are associated with their amassing of wealth. But the antitrust laws are not the weapons with which to deal with non-monopolistic concentrations of wealth.

\section{Patent Acquisition as Merger}

The Report fails to mention in either the Merger or Patent Chapters whether the acquisition of patents from a rival may be prevented under section 7 of the Clayton Act. The control of mergers should extend, of course, to the accumulation by one firm of any form of property whose concentration of ownership will reduce competition in an important market, and therefore it should extend to the accumulation of patents. The Report mentions the Sherman Act as limiting the accumulation of patents with intent to monopolize, ${ }^{18}$ but patents of a rival are part of his "assets" and presumably subject also to the Clayton Act's mandate against acquisition of "any part of the assets." The ambiguous language of the Report seems to ask for a clearer showing of impairment of competition in the case of patent acquisition than in the case of ordinary mergers, but no justification is given for this priority of patent rights over antitrust objectives (which pervades section $\mathrm{v}$ of the Report), and I doubt that one can be given.

The anti-merger statute, it is evident, is the fundamental element of our preventive antitrust policy. It seems a conservative estimate that fully one-half of the major cases which have been brought under the Sherman Act have been necessary simply because we did not have an effective anti-merger policy in the past. The antitrust agencies should take this lesson to heart; the new statute deserves a place of high priority in the antitrust policy of the United States.

16. REPORT at 227 n.21. 